\title{
Gayrimüslimlere Uygulanan Ağır Ceza Türleri: 37 Numaralı Kalebent Defteri Örneği
}

\author{
Özlem POYRAZ \\ Kırșehir Ahi Evran Üniversitesi \\ ozlemsahin38@gmail.com \\ ORCID ID: 0000-0003-2721-2401 \\ Merve ÖNER \\ Kırşehir Ahi Evran Üniversitesi \\ gizemmonerr@gmail.com \\ ORCID ID: 0000-0002-9900-7442 \\ Seyfettin ÖVÜNÇ \\ Kırşehir Ahi Evran Üniversitesi \\ seyfettinoyunc@gmail.com \\ ORCID ID: 0000-0002-2482-1730
}

\begin{tabular}{lrr} 
Araştırma Makalesi & DOI: $10.31592 /$ aeusbed.816588 \\
\hline Geliş Tarihi: 27.10 .2020 & Revize Tarihi: 09.03.2021 & Kabul Tarihi: 09.03.2021
\end{tabular}

\section{Atıf Bilgisi}

Poyraz, Ö., Öner, M. ve Övünç, S. (2021). Gayrimüslimlere uygulanan ağır ceza türleri: 37 Numaralı Kalebent Defteri örneği. Ahi Evran Üniversitesi Sosyal Bilimler Enstitüsü Dergisi, 7(1), 272-286.

\section{ÖZ}

Çok geniş bir coğrafyada hüküm süren Osmanlı Devleti'nin farklı din, dil ve millet unsurlarını tek bir çatı altında asırlarca yönettiği bilinmektedir. II. Mahmut döneminde ise siyasi, sosyal ve iktisadi anlamda çalkantılı bir süreçten geçilmiştir. Buna rağmen devlet-toplum ilișkisinin korunmasına ehemmiyet verilmiștir. Bu ilişkinin korunmasına yönelik kanunnameler oluşturulmuş; usûl ve kaidelerin ihlal edildiği durumlarda ise suçlular millet ayrımına gidilmeksizin cezalandırılmışır. Bu araştırmanın amacı, 37 Numaralı Kalebent Defteri’nin gayrimüslimlere yönelik hükümlerinden yola çıkarak uygulanan ağır ceza türlerinin tespitini yapmak ve dönemin ağır ceza anlayışına dair sistemi ortaya çıkarmaktır. Suç ile suçlu profílinin ortaya çıkarılmasında, gayrimüslimler arasındaki suç eğiliminin aydınlatılmasında kalebent defterleri ayrı bir önemi bulunmaktadır. Araştırma, 1823-1826 yılları arasında sınırlandırılmıştır. Gayrimüslimlere yönelik uygulanan cezalar sürgün, ikamet, kalebent, manastırbent, palankabent ve kürek cezaları olarak tasniflenmiștir. Cemaat liderlerinin cezalandırmalardaki etkisi ve Müslim-gayrimüslim suçluluk oranları da incelenmeye tabi tutulan sorulardan olmuştur. Gayrimüslimlerin yoğunluklu olarak ayinlere mugayir hareket suç çeşidini işlediği bulgusuna ulaşılmıştır.

Anahtar Kelimeler: Sürgün, kalebent, manastırbent, palankabent, kürek.

\section{Heavy Penalties' Types of Non-Muslims: For Example of 37 Numbered Kalebent Book}

\begin{abstract}
It is known that the Ottoman Empire, which ruled over a wide geography, different religious, languages and nationalities under one roof for centuries. When it comes to II $^{\text {nd }}$ Mahmut period, the state is going through troubled process for political, social and economic process. Despite this, emphasis has been placed on the preservation of the state-society relationship. Legislative laws have been created to protect this relationship and in cases where the rules and procedures were violated, the criminals were punished without making any distinction between nations. The aim of this research is to determine the types of heavy penalties applied only to non-Muslims, based on the provisions of 37 Numbered Kalebent Book and has been determined as revealing the system of severe punishment of the period. Kalebent boks have an special importance in determining the profile of crime and criminal and illuminating the crime trend among non-Muslims. The research was limited between 1823-1826 years. The punishments imposed on non-Muslims are classified as exile, residence penalty, fortress, monastic punishment, military castle and penal. The impact of community leaders on punishments and Muslim or non-Muslim guilt rates were also among the questions that were examined. It has been found that non-Muslims mostly commit the crime of acting unlike rituals.

Keywords: Exile, fortress, monastic punishment, military castle penalty, servitudes and shackles.
\end{abstract}

\section{Giriş}

Osmanlı Devleti kuruluş aşamasında sadece Müslüman unsurların yer aldığı bir uç beyliği iken zamanla sınırlarını genişletmiş ve çeşitli gayrimüslim unsurları da bünyesine dâhil etmiştir 
(Köprülü, 1959, s. 50). Bu nedenle kuruluşundan kısa bir süre sonra etnik bakımdan kozmopolit, din ve kültür bakımından ise hayli çeşitli, toplulukların bir arada yaşadığı bir ülke konumuna yükselmiştir. Devlet yapılanmasında yönetici zümre dışında kalan unsurlar reaya olarak isimlendirilmiştir. Reayayı ise mensup olunan din ya da bulunduğu mekâna göre farklı statüleri bulunan muhtelif gruplar oluşturmuştur. Müslim ya da gayrimüslim fark etmeksizin devlete belli ölçüde vergi vermek ve belli mükellefiyetleri yerine getirmekle yükümlü tutulan reayanın görevleri devlet başkanına itaat edip kamu hukukunu gözetmek olarak belirlenmiştir. Toplum ise kendi içinde dinî bir tasnife tabi tutulmuştur. $\mathrm{Bu}$ tasnife göre toplum hak ve yükümlülükleri birbirinden farklı olan Müslim ve gayrimüslim unsurlar olmak üzere ikiye ayrılmıştır (Saydam, 1999, s. 159-160). Fakat bu ayrımda din bireyleri ve grupları birbirinden ayırt etmeye yarayan bir araç olmuştur. Söz konusu gayrimüslim tabiri genel olarak Müslümanlar dışında kalan bütün dini grupları ifade etmek için kullanılmıştır (Güneş, 2015, s. 3).

Osmanlı Devleti İslam hukuk sisteminin uygulandığı bir ülke olması bakımından darül-islam olup, bu durum Müslüman reayanın ya da gayrimüslim reayanın az ya da çokluğu ile ilgili olmayıp yönetici unsurun Müslüman olmasından kaynaklanmaktadır. Osmanlı Devleti'nin şer’i hukuku benimsemesi de İslami kimliğinden gelmektedir. Hukuk yapılanmasında şüphesiz ki şer'i hukuk önemli bir paya sahiptir. İslam hukukuna göre suçlar had, kısas ve ta'zir olarak üç kategoriye ayrılmıştır (Akgündüz, 2006, s. 106). Ta'zir cezaları zamanın ihtiyaçlarına göre yeniden şekillendirilebilme olanağına sahip bir alan olması bakımından laik bir nitelik taşımaktadır (Taner, 1940, s. 226). Fatih Sultan Mehmet döneminden (1451-1481) beri yasalaştırılmış kanunnameler ile ta'zir alanındaki boşluğun doldurulmasına yönelik hükümlere yer verilmiştir. Bu nedenledir ki ta'zir grubunu örfi hukukun kanunlaşmış hali olarak tanımlamak mümkündür. Eskiden beri var olan mevcut hükümlerinin bir araya getirilmesi şeklinde oluşturulan bu kanunname, çeşitli dönemlerde revize edilmekle birlikte Tanzimat döneminin (1839-1876) sonuna dek yürürlükte kalmıştır (Akgündüz, 1991, s. 128-135).

İslam hukuku bünyesinde yer almayan birçok eylemin cezaî yaptırımı ulü'lemr yani padişahın yetkisine bırakılmıştır (Yurtseven, 2001, s. 272). Oluşturulan kanunnamelerde yönetici, yasama yetkisini kullanırken tam bir serbestiye sahip olmayıp suçlar ve cezalarını İslam'ın çizdiği sinırlara uygun olarak tespit etmekle yükümlü tutulmuştur (Ergin, 2016, s. 22). Hükümdarın iradesi ile oluşturulan bu kanunlar dini hukuku feshetmek için değil onu tamamlamak için ilan edilmiştir (Heyd, 1984, s. 642). Yerel anlamda adaleti yönetici adına kadılar yürütmekle mükellef tutulmuştur. Kadılar yönetici adına adaleti dağıtan, gücünü doğrudan yöneticiden alan bağımsız yargıçlardır (Koç ve Tuğluca, 2006, s. 8). Dolayısıyla yargı yetkisinin kadıya zaman, mekân ve görev yetkisi açısından çizilen sınırlarla devredildiğini ifade etmek yanlış olmayacaktır.

Gayrimüslimlerin medeni hukuk alanına giren konularına yönelik kendi cemaat mahkemelerine başvurma hakkı saklı tutulmuştur. Dolayısıyla devlet, kilise mahkemelerinin belirli sınırlar dâhilinde yaşatılmasını uygun bulmuştur. Fakat bu gibi davalarda da gayrimüslimlerin kadı mahkemelerine başvurma hakkı mevcuttur (Koç ve Tuğluca, 2006, s. 21). Cemaat mahkemesi kararlarının ancak taraflar rıza gösterdiği takdirde uygulanabilmesi nedeniyle gayrimüslimler de çoğunlukla her türlü davalar için şer’i mahkemelere başvurmuştur. Zaten devletin mahkemelerdeki asıl karar mercii de şer'i (kadı) mahkemelerdir (Saydam, 1999, s. 277). Şer'i mahkemelerde herhangi bir dini ayrıma gidilmeksizin davalar karara bağlanmıştır.

Ta'zir, kelime anlamı olarak men etmek, engel olmak, edeplendirmek, kınamak, şiddetli dövmek anlamlarına gelmektedir (Yakut, 2006, s. 25). Ta'zir suçlarına uygulanan cezalar idam, celd (sopa ve çomak), hapis, sürgün (nefy), ögüt verme, kınama, tehdit, para, kürek, prangabentlik, kalebentlik, alnın dağlanması, sakalın kesilmesi (Poyraz, 2017, s. 542) olarak tayin edilmiştir. Söz konusu cezaların uygulanması ile suçluların ıslah edilmesi ve toplumsal istikrarının sağlanması amaçlanmıştır.

Araştırma 37 Numaralı Kalebent Defteri'nin gayrimüslimlere yönelik hükümlerinden yola çıkarak II. Mahmut döneminde gayrimüslimlere uygulanan ağır ceza türlerinin ortaya çıkarılmasını 
hedeflemiştir. Araştırmada nitel araştırma yöntemlerinden doküman analizi yaklaşımı kullanılmıştır. Mevcut defterden yola çıkarak dönemin milli taksime göre suç ile suçlu profilini tespit edebilmek, gayrimüslimlerdeki suç eğilimini ortaya çıkarabilmek mümkündür. Cezalandırma süreçlerinde gayrimüslim cemaat liderlerinin etkisinin olup olmadığı ve gayrimüslim unsurların Müslümanlara kıyasla suç işleme oranları da incelemeye tabi tutulan meselelerden olmuştur. Söz konusu araştırma ile 1823-1826 yılları arasında gayrimüslimlere yönelik uygulanan ağır ceza türlerinin aydınlatılmasına yönelik boşluğun doldurulması amaçlanmıştır.

\section{Numaralı Kalebent Defteri’nin Özellikleri}

Suçluların cezalandırılma sebepleri ve bunlar hakkında bilgiler sunan kalebent defterleri, hürriyet kısıtlayıcı ve hürriyet bağlayıcı özellikleri bulunan ağır cezaları ihtiva etmesi bakımından dikkate değerdir. Hapishane binalarının bulunmayışı nedeniyle devlet sürgün, ikamet, kalebent, manastırbent, palankabent ve kürek gibi cezalara başvurmuştur. Defterlerde herhangi bir dini ayrıma gidilmeksizin suçlular cezalandırılmıştır. Suçluların kimliği, suç çeşitleri, ceza türleri ve bazen de cezaların sonlandırılmasına yönelik ıtlak hükümleri kronolojik bir sıraya göre kayıt altına alınmıştır. Başbakanlık Osmanlı Arşivi 989 numaralı Divan-1 Hümayun Kataloğu'nda H. 1135-1256 / M. 17221841 tarih aralığındaki hükümleri içeren 44 adet ve 980 numaralı Bab-1 Asafi Defterleri kataloğunda H. 1091-1239 / M. 1680-1824 tarih aralığındaki hükümleri içeren birkaç sayfa ile formattan oluşan 6 adet defter parçası mevcuttur.

Divani hat ile yazılan defterde her sayfada ortalama 3 ila 5 arasında hükme yer verilmiştir. Belgeler hükmün sol tarafina gelecek şekilde Hicri takvim kullanılmak üzere tarihlendirilmiştir. Günler ise Eva'il (ilk on gün), Evâsıt (ikinci on gün) ve Evâhir (son on gün) olmak üzere tasniflendirilmiştir. Hükümler kayıt altına alınırken üzerlerine sonradan eklenecek şerhler için boşluklar bırakılmışıır. Bu şerhler vusûl ve menfiyyen meks u ikâmet olunduğunu nâtık-ı vârid olan i'lâmı mazmûnu bâ-fermân-ı âli şerh verildi ve ıtlâkı için emr-i âli yazılmıştır şeklindedir. Suçlunun ceza mahalline ulaştırılması ve salıverilmesine yönelik bilgilere bu şerhler içerisinde yer verilmiştir. Gayrimüslim suçlular, mensup oldukları dinin yetkilisi tarafından durumun merkeze bildirilmesi suretiyle cezalandırılmıştır. Bu durumu Rum Patriki Der-sa'âdetimde mukîm cemâ 'at-ı metropolidanı südde-i sa'âdetime takdîm eylediği bir kut'a arzuhâlleriyle istid'â olunduğuna binâ'en (BOA, A.DVNS.KLB.d., 37, 92-14) veya tevabî' Ermeni Patriği Boğos nâm rahip südde-i sa'âdetime bir kut'a memhûr arzuhâl takdîmiyle istid'â etmekten nâş̧i (A.DVNS.KLB.d., 37, 4-2) gibi ifadelerinden de anlamak mümkündür. Yine defterdeki verilerden yola çıkarak gayrimüslim suçluların ceza bölgelerine yasakçı aracılığıyla gönderildiği anlaşılmaktadır. Bunu 1825 yılında Kartal nahiyesine tabi Heybeliada Ayapetre Manastırı Rum taifesinden Sokrotibos adlı rahibin kendi halinde hizmetiyle meşgul olmayıp ayinlerine mugayir hareket nedeniyle defaatle uyarılsa da uslanmayıp tedip ve terbiyeye ihtiyacı olduğu gerekçesi ile yasakçı maarifetiyle Dimetoka'ya sürgüne gönderilmesi (A.DVNS.KLB.d., 37, 157-1) örneğinden de anlamak mümkündür. Defterde yasakçılarla birlikte harbecilere de sıklıkla yer verilmiştir. Harbecilerin suçluları hapsetmekle görevli kimseler olduğu anlaşılmaktadır (Ünal, 2011, s. 294). 1824 yılında Cephane-i Amire kurşuncubaşısı olan Markati adlı Yahudi'nin memuriyetine ihanet etmesi nedeniyle harbeci mübaşiretiyle Antalya Kalesi'ne kalebent olarak gönderilmesi (A.DVNS.KLB.d., 37, 137-4) buna örnektir. Cezalandırılma süresinin 19 ay kadar sürdüğü verilerine ulaşılmıştır. Suçluların yasakçı marifetiyle ceza bölgesine gönderildiği, orada harbecilerin suçluları teslim aldığı ve ardından yasal sürecin başlatılıp takip edilmesi için kadının tembihlendiği anlaşılmaktadır.

Belgelerde hükümlere başlanırken öncelikli olarak olayın meydana geldiği yer, ardından cezanın çekileceği yer görevlisi hakkında bilgi sunulmuştur. Kayseri ve Trabzon Kazâlar Nâ'iblerine Hüküm ki ifadesi buna örnektir. Hükümler yazılırken suçlunun suç mahalli, adı, unvanı, dini aidiyeti, milliyeti, suç sebebi, uygulanacak olan ceza yöntemi ve ceza mahalline dair bilgilere yer verilmiştir. Bütün bu verilerden yola çıkarak dönemdeki suç ve suçlu profilini çıkarmak, ceza türlerini tespit edebilmek, toplumdaki dini taksime göre suçluluk oranını tespit edebilmek, ceza türü ve ceza mahalli arasındaki ilişkiyi tespit edebilmek mümkündür. 1823-1826 yılları arasında tespit edilen ağır ceza türlerini aydınlatabilmek araştırmanın temel problemi olarak belirlenmiştir. 


\section{Ağır Ceza Türleri}

1823 ve 1826 y1lları arasında tutulmuş olan 37 numaralı Kalebent Defteri bünyesinde toplam 1.319 adet hüküm ve bu hükümlere bağlı olarak 278 adet surete yer verilmiştir. Bu hükümlerden 151 adetinin gayrimüslimlere yönelik hükümler olduğu tespit edilmiştir. Müslim-gayrimüslim suç oranı kıyaslandığında gayrimüslimlerin suçluluk oranının hayli düşük olduğu anlaşılmaktadır. 92 mahkûm ile sürgün cezası alan gayrimüslim sayısının fazlalığı dikkat çekmektedir. Bunu 57 mahkûm ile kalebentlik, 18 mahkûm ile manastırbentlik, 3 mahkûm ile palankabentlik, 3 mahkûm ile kürek ve 2 mahkûm ile ikamet suçlusu takip etmiştir. Araştırmayı aydınlatabilmek için 6 araştırma sorusu belirlenmiştir. Bunlardan ilki sürgün cezalarıdır.

\section{Sürgün Cezaları}

1823-1826 yılları arasında tespit edilen araştırma sorularından ilki sürgün cezaları olarak belirlenmiştir. Osmanlı Devleti'nin üç şekilde sürgün politikasına başvurduğu bilinmektedir. Bunlardan ilki devletin kuruluş ve yükseliş dönemlerinde devlet politikası olarak yeni fethedilen yerlere Türk unsurunu iskân ettirmek amaciyla yürüttüğü toplu sürgün uygulamasıdır ki buna aşiretlerin cezalandırılması amacıyla sıklıkla başvurulmuştur (Halaçoğlu, 2014, s. 137). İkincisi mekân değiştirme yoluyla merkezden uzaklaştırılma amacı taşıyan sürgün uygulamasıdır ki bununla da daha çok Der-saadet'te muhalif olan kişilerin siyasi gerekçelerle merkezden uzaklaştırılması amaçlanmıştır. Üçüncüsü ise cezaî gerekçelerle uygulanan sürgün politikasıdır ki bununla da şehir veya köy halkı içinde yaşayan yaramaz ve sabıkalı kişilerin toplumun huzurunu bozmayacak şekilde başka bir bölgeye gönderilerek suçlunun nefsini ıslah etmesi amaçlanmıştır (Acehan, 2008, s. 16).

Yavuz Sultan Selim döneminden (1512-1520) itibaren her dönemde kanunnamelerde sürgün cezasına yer verilmiştir (Akgündüz, 1991, s. 106). Suçlunun suç mahallinden uzaklaştırılarak yalnızlaştırılması ve düşünmeye sevk edilmesi ve aynı zamanda da suç mahallinde istikrarın korunması da amaçlanmıştır. İşlenen suçların toplumsal etkisi farklı olduğundan tek tip bir ceza uygulamasına gidilmemiştir (Poyraz, 2020, s. 501).

Defterden yola çıkarak gayrimüslimlerin işledikleri suç ile suçlu profilini ve gayrimüslim unsurların milli kimliğini tespit edebilmek mümkündür. Toplam 92 adet sürgün cezası alan gayrimüslim suçlu tespit edilmiştir. Bu suçluların 40'1 Ermeni, 19'u Rum, 1'i Yahudi olup geriye kalan 32 suçlunun milli kimliğine dair herhangi bir bilgiye yer verilmemiştir. 9 kadın suçlunun varlığ da tespit edilmiştir. Dolayısıyla dönemde kadınların da suç unsuruna iştirak ettiği verilerine ulaşılmıştır. Kadın suçluların ise neredeyse yarısını Ermenilerin oluşturduğu tespit edilmiştir.

Defterde yer alan suç çeşitleri; ahalinin huzurunu bozmak / ahaliye zulmetmek, ayinlere mugayir hareket, darphaneye ihanet, Ermeni reaya kızlarını Avrupalılarla evlendirmek, eski Rum patriğine tarafgirlik, fitne ve fesat çıkarmak, fiyat-1 nükut düzenini bozmak, hilaf-1 rıza hareket, haneye tecavüz, kendi halinde olmamak, maden nizamını bozmak, mahallin düzenini bozma, mukataa nizamını bozma, memleket-i ihtilal ve ifsat, patrikhane umuruna müdahale, sahte belge düzenlemek, şeriat dışı / edebe aykırı davranışlar, tecavüz / ırza saldırı / fuhşiyat, terbiyeye muhtaç olma, tersane mahzeninde uygunsuz hareket, uygunsuz hareket, vazifesi olmayan işlere müdahale etmek, vazifesini yerine getirmemek olarak belirlenmiştir. Gayrimüslimlerin işlediği ve sürgün cezasına sebep olan 23 ayrı suç çeşidinin varlığı tespit edilmiştir (Tablo 1).

Tablo 1

Sürgün Cezalarının Uygulandiğı Suç Çeşitleri, Hüküm Numaraları ve Mahkûm Sayıları

\begin{tabular}{clcc}
\hline Sıra & \multicolumn{1}{c}{ Suç Çeşidi } & \multicolumn{1}{c}{ Hüküm Numarası } & $\begin{array}{l}\text { Mahkûm } \\
\text { Sayıs }\end{array}$ \\
\hline 1 & $\begin{array}{l}\text { Ahalinin huzurunu } \\
\text { bozmak / Ahaliye } \\
\text { zulmetmek }\end{array}$ & $35-2,35-3,218-3,221-2,247-2,275-3$. & 8 \\
& Ayinlere mugayir & $4-3,29-1,34-5,35-1,38-4,42-3,43-1,46-1,50-5,56-2,61-$ & 31
\end{tabular}


hareket

3 Darphaneye ihanet

4 Ermeni reaya kılarını

Avrupalilarla

evlendirmek

$5 \quad$ Eski Rum patriğine

tarafgirlik

6 Fitne ve fesat çıarmak

$7 \quad$ Fiyat-1 nükut düzenini

bozmak

8 Hilaf-1 riza hareket

9 Haneye tecavüz

10 Kendi halinde olmamak

11 Maden nizamını

bozmak

12 Mahallin düzenini

bozma

13 Mukataa nizamını

bozmak

14 Memleketi ihtilal ve

ifsat

15

Patrikhane umuruna

müdahale

16 Sahte belge

düzenlemek

Şer'iat dışı/edebe aykırı davranışlar

18 Tecavüz/ırza saldırı/

fuhşiyat

19 Terbiyeye muhtaç olma

20 Tersane mahzeninde

uygunsuz hareket

21 Uygunsuz hareket

22 Vazifesi olmayan işlere

müdahale etmek

23 Vazifesini yerine getirmemek
$6,76-4,83-4,84-1,84-2,84-3,85-3,105-2,108-1,159-5$, $175-3,183-1,199-1,210-3,232-1,232-3,238-2,273-5$.

$163-2$.

$170-5$.

$175-1$.

9-2, 51-4. 2

$85-2,220-3,220-4$.

12-4, 17-4, 157-1, 161-4, 174-3, 199-3, 234-4, 272-4. 8

245-3.

29-2, 29-4, 29-5, 43-3, 161-2, 161-3, 161-5, 194-1. 8

22-3.

$116-2 . \quad 2$

$232-4$.

$150-3,238-3,260-3$.

233-1. 1

$127-2$.

$107-1$.

$31-4$.

231-5.

260-3, 260-4, 260-5, 260-6.

$9-3,51-1,51-2,127-3,150-1$. 5

29-3, 72-1, 83-1, 127-5 4

$141-3$. 1

Toplam

Gayrimüslim suçluların ayinlerine mugayir hareket suç çeşidini yoğun olarak işlediği bulgusuna ulaşılmıştır (Tablo 1). Söz konusu suç çeşidini ahalinin huzurunu bozmak / ahaliye zulüm etmek, hilaf-1 rıza hareket ve kendi halinde olmamak takip etmiştir. Kendi halinde olmayıp ayinlere mugayir hareket nedeniyle 1823 yllında Ermeni taifesinden Sivas sancağı mütemekkinlerinden Margos oğlu Ağop (A.DVNS.KLB.d., 37, 84-1), Toval oğlu Toran (A.DVNS.KLB.d., 37, 84-2) ve Margos oğlu Moses (A.DVNS.KLB.d., 37, 84-3) adlı zimmilerin bazı kimseleri rencide edici hareketlerinde 1srarc1 olması üzerine Ermeni patriği Karabet'in arzuhali neticesinde Bitlis'e gönderilmesi meselesi buna örnektir. Söz konusu meselede ceza sürelerinin 7 ay kadar sürdüğü tespit edilmiştir. 1825 yılına ait diğer bir veride de Rum milletinden olup Gümülcine kazası mütemekkinlerinden Aci Zafiraki adlı zimminin bir müddetten beri kendi halinde olmayıp ayinlerine mugayir hareket nedeniyle defaatle uyarılmış olsa da uslanmaması üzerine Rum metropolitinin arzuhali üzerine yasakçı marifetiyle Muğla'ya sürgüne gönderilmesi (A.DVNS.KLB.d., 37, 183-1) meselesi ile karşılaşılmıştır. Her iki hükümden de anlaşıldığı üzere gayrimüslimlerin cezalandırılmalarına yönelik yazışmaların patrikler aracılığıyla yapıldığı anlaşılmaktadır. Bu durum belgelere Rum Patriki der-sa'âdetimde mukim cemâ'at-ı metropolidanı Südde-i sa'âdetime takdîm eylediği bir kut'a arzuhâlleriyle istid'â olunduğuna binâ'en şeklinde yansitılmıştır. Müslüman suçluların çavuş mübaşiretiyle, gayrimüslim suçluların ise yasakçı mübaşiretiyle ceza mahalline götürüldüğü anlaşılmaktadır. Yine aynı şekilde ağır ceza uygulamalarına geçilmeden önce suçluların 
birkaç kez uyarıldığı fakat suç işlemeye devam ettikleri takdirde cezalandırıldıklarını ifade etmek de mümkündür.

Defterde az sayıda da olsa kadın suçlu ile karşılaşılmıştır. Tespit edilen verilerden yola çıkarak kadın suçluların kısa süreli ve yakın sürgün bölgelerine gönderildiği anlaşılmaktadır. 1825 yılında Ermeni taifesi Beyoğlu mütemekkinlerinden Çiçekçi Artin'in zevcesi Serphori'nin Ermeni kızlarını Avrupalı erkeklerle evlendirmeye teşebbüs ettiği gerekçesi ile İstanbul Ermeni patriği Karabet'in arzuhali neticesinde yasakçı marifetiyle Çorlu'ya sürgüne gönderilmesi (A.DVNS.KLB.d., 37, 170-5) bunun örneklerindendir.

Tercih edilen cezalandırılma bölgelerinin çeşitliliği dikkat çekmektedir. Söz konusu bölgeler Adana (3), Adapazarı (1), Amasya (3), Ankara (4), Aydıncık (1), Bafra (1), Bandırma (2), Bitlis (3), Bolu (3), Bursa (4), Çankırı (3), Çemişgezek (1), Çorlu (1), Dimetoka (5), Diyarbakır (4), Eğin (3), Erzurum (1), Gelibolu (2), Giresun (1), Gümüşhane (1), Hacioğlu Pazarcık (1), İslimiye (2), İznik (3), İznikmid (3), Kapudağ1 (1), Karaman (1), Kastamonu (1), Kavala (1), Kayseri (2), Kemah (1), Kedagra (1), Kütahya (1), Konya (1), Mihaliç (2), Muğla (2), Niğde (1), Rodos (1), Safranbolu (1), Selanik (2), Silivri (1), Sinop (2), Sivas (1), Tekfurdağı (2), Trabzon (2), Tokat (5), Tosya (1), Ünye (1), Van (1), Varna (1) şeklinde tespit edilmiştir. Toplamda 49 ayrı sürgün bölgesine ulaşılmıştır. Bölgeler içerisinde Dimetoka ve Tokat'ın başı çektiği anlaşılmaktadır.

Sürgün cezası alan suçluların kaçmasını engelleyebilmek ve kontrollerini sağlayabilmek için sahil kaleleri olan şehirler ya da adalar tercih edilmiştir (Poyraz, 2020, s. 505). 1823 y1lında Eğin mütemekkinlerinden Ermeni taifesinden Agyanik oğlu Agayin adlı zimminin yasakçı marifetiyle Trabzon'a sürgüne gönderilmesi (A.DVNS.KLB.d., 37, 29-3) ya da yine aynı yıl Ermeni taifesinden Kandiye'de mütemekkin Tatiyos adlı rahibin kendi halinde olmayarak ayinlerine mugayir hareket nedeniyle yasakçı marifetiyle Rodos'a sürgüne gönderilmesi (A.DVNS.KLB.d., 37, s. 56-2) bunu kanitlamaktadir.

\section{İkamet Cezaları}

1823-1826 yılları arasında tespit edilen araştırma sorularından ikincisi ikamet cezalarını aydınlatmak olarak belirlenmiştir. Ta'zir cezaları içerisinde yer alan ağır cezalardan biri de zorunlu olarak bir bölgede ikameti gerektiren cezalardır. Sürgün ile benzer bir mahiyeti bulunmakla birlikte ikamet cezası alan suçluların aileleri ile birlikte yaşadığı yerden uzaklaştırılarak memleketi ya da başka bir bölgede yaşaması zorunlu hale getirilmiştir. Suçluların genellikle bir çiftlik ya da arpalık gibi şahsi mülklerde belirli bir süre ikamet ettirilmek sureti ile infazının gerçekleştirildiği (Uz, 2018, s. 457) bilinmektedir. Genellikle ağır ceza alan suçluların affedilme halinde uygulandığını da ifade etmek yanlış bir yaklaşım olmayacaktır (Baytimur, 2011, s. 184). Suçluların ikamet bölgesinde kalmaması durumunda daha ağır bir cezaya başvurulduğu anlaşılmaktadır. Suçluların affedilmeleri için diğer cezalarda olduğu gibi merkezden onay gerekmiştir.

Tablo 2

İkamet Cezalarının Uygulandĭ̆g Hüküm Numaraları ve Mahkûm Sayıları

\begin{tabular}{lll}
\hline Sıra & Hüküm Numarası & Mahkûm Sayısı \\
\hline 1 & & 2 \\
Toplam & $161-1,180-1$. & 2 \\
\hline
\end{tabular}

Dönemde gayrimüslimlere yönelik uygulanan 2 ikamet cezası ile karşılaşılmıştır (Tablo 2). Söz konusu suçluların daha önce işlemiş oldukları suç çeşidine dair herhangi bir veriye rastlanmamıştır. Her iki hüküm de 1825 yılına aittir. Bunlardan birincisi İznikmid'e sürgüne gönderilen Osmanpazarı kazasından Bulgar asıllı olan Boğdan eski kaymakamı İstefnaki'nin eşi ve 6 çocuğu ile birlikte 3 seneden beri sürgünde olduğu ve 1828 senesinde İznikmid'e havale olunmas1 gerektiği ile hiçbir tarafa salıverilmeksizin ikameti gerektiğinin aktarıldığı (A.DVNS.KLB.d., 37, 1611) belgedir. Diğeri ise Hüdavendigar sancağına ikamet ettirilmek üzere gönderilen ve isim bilgisine 
yer verilmeyen hiçbir yere salıverilmemesi konusunda dikkat edilmesi gerektiği aktarılan (A.DVNS.KLB.d., 37, 180-1) hükümdür. İkamet cezas1 verilen suçluların ailelerinin yanlarında bulunması nedeniyle suç unsurundan uzaklaşacakları düşünülmüştür.

\section{Kalebent Cezaları}

1823-1826 yılları arasında tespit edilen araştırma sorularından üçüncüsü kalebent cezalarını aydınlatmak olarak belirlenmiştir. Osmanlı'da 18. yüzyıldan itibaren suçluların kale sınırları içerisinde muhafazasını öngören kalebentlik cezası, bir şehir ya da bir kasabada oturmaya mecbur tutulma mahiyeti taşıması nedeniyle bir çeşit hapis, suç işlediği yerlerden uzaklaştırılarak başka yerlerdeki kalelere sürülmesi nedeniyle bir çeşit sürgün cezası olarak tanımlanabilmektedir (Avc1, 2002, s. 134135). Osmanlı Devleti'nde siyaset cezasını gerektirenler suçlar dışındaki diğer suçlar için teşhir, dayak atma, para cezası, kürek cezası, kalebentlik ve sürgün gibi cezalar uygulanmıştır (Erim, 1984, s. 80). Kalebentlik cezası ile suçlu belirlenen kale sınırları içerisinde serbestçe gezebilme olanağına sahip olmuştur. Sürgüne göre daha ağır cezai nitelik taşıan kalebentlik cezasının incelenen dönemde gayrimüslimlere en çok uygulanan ikinci ceza türü olduğu tespit edilmiştir.

Kamu düzenini bozmaya yönelik eylemlere verilen bir ceza türü (Poyraz, 2020, s. 508) olup suçlular meşakkatli işlerde çalıştırılmamış, teşhir edilmemiş ve hapsedilmemiştir. Kale içerisinde de serbest dolaşım imkânına sahip olmakla birlikte, kale dışındaki işlerini yanlarında görevli bir memur bulunmak kaydıyla gerçekleştirebilmişlerdir (Gökçen, 1987, s. 61).

Gayrimüslimlere uygulanan kalebentlik cezası gerektiren 9 ayrı suç çeşidi ile karşılaşı1mıştır. Bunlar; ayinlere mugayir hareket, görevini kötüye kullanmak, hilaf-1 resm-i raiyyet, kendi halinde olmamak, memleketi ihtilal ve ifsad, teslim ettiği mühimmatı incelememek, uygunsuz hareket, sahte belge düzenlemek, sebebi belli olmayan suçlardır. Söz konusu suç türleri içerisinde 26 mahkûm sayısı ile ayinlere mugayir hareket suç çeşidinin başı çektiği verilerine ulaşılmıştır. Bununla alakalı örneklerden biri 1823 yılında Bergama mütemekkinlerinden Yanaki Elekçi adlı zimminin Rum patriğinin kendi halinde olmayıp bir müddetten beri birkaç kez uyarılmış olsa da ayinlere mugayir harekete devam ettiğini bildirmesi üzerine yasakçı marifetiyle Dimetoka Kalesi'ne kalebent olarak gönderilmesidir (A.DVNS.KLB.d., 37, 38-3). 1826 yılına ait diğer bir veride ise Mekri (Fethiye) kazası Kayı karyesi mütemekkinlerinden Rum milletinden Oyedin oğlu Aci Nikola ve diğer Kara Nikola adlı zimmilerin bir müddetten beri kendi halinde olmayıp, yalana meyledip, türlü rezilliklere cüret edip, ayinlere de mugayir harekete başvurmaları nedeniyle birkaç kez uyarılmış olsalar dahi uslanmadıkları gerekçesi ile yasakçı marifetiyle Karahisar-1 sahip Kalesi'ne gönderilmeleri (A.DVNS.KLB.d., 37, 171-1) meselesi ile karşılaşılmıştır. Birden fazla suç çeşidinin birlikte işlendiği bu meselede mahkûmların muhafazasına ayrıca önem verilmesi gerektiği de aktarılmıştır. Ceza süresinin 1 yıl kadar sürdüğü de (A.DVNS.KLB.d., 37, 249-2) tespit edilmiştir. Örneklerden de anlaşıldığ 1 üzere suçluların cezalandırılmadan önce uyarıldığı, hala suç işlemeye devam ettikleri takdirde cezalarının uygulandığı meselesidir. Verilerde bu durum her ne kadar nush u pend olunmuş ise de mütenebbih olmayarak ifadesi ile aktarılmıştır.

Tablo 3

Kalebent Cezalarının Uygulandiğı Suç Çeşitleri, Hüküm Numaraları ve Mahkûm sayıları

\begin{tabular}{|c|c|c|c|}
\hline Sira & Suç Çeşidi & Hüküm Numarası & $\begin{array}{l}\text { Mahkûm } \\
\text { Sayısı }\end{array}$ \\
\hline 1 & $\begin{array}{l}\text { Ayinlere mugayir } \\
\text { hareket }\end{array}$ & $\begin{array}{l}17-2,17-3,38-3,76-3,103-3,108-4,110-2,116-3,116-4,165- \\
1,170-4,181-3,183-2,192-4,194-2,198-5,212-4,226-1, \\
236-1,238-1,241-3,249-1,250-2,258-3,280-2 .\end{array}$ & 26 \\
\hline 2 & $\begin{array}{l}\text { Görevini kötüye } \\
\text { kullanmak }\end{array}$ & ( & 1 \\
\hline 3 & Hilaf-1 resm-i raiyyet & $100-2,100-3,104-5$ & 16 \\
\hline 4 & $\begin{array}{l}\text { Kendi halinde } \\
\text { olmamak }\end{array}$ & $165-2,171-1,219-6,225-1,260-2$ & 6 \\
\hline 5 & $\begin{array}{l}\text { Memleketi ihtilal ve } \\
\text { ifsad }\end{array}$ & $226-2$ & 1 \\
\hline
\end{tabular}




\begin{tabular}{|c|c|c|c|}
\hline 6 & $\begin{array}{l}\text { Teslim ettiği } \\
\text { mühimmatı } \\
\text { incelememek }\end{array}$ & $159-1$. & 1 \\
\hline 7 & Uygunsuz hareket & $8-3,66-3,254-3$ & 3 \\
\hline 8 & $\begin{array}{l}\text { Sahte belge } \\
\text { düzenlemek }\end{array}$ & $51-6$. & 1 \\
\hline 9 & Sebebi belli olmayan & $26-3$. & 2 \\
\hline Toplam & & & 57 \\
\hline
\end{tabular}

Kalebent cezası alan toplam 57 gayrimüslim suçlu ile karşılaşılmıştır (Tablo 3). Bunların 30’u Rum, 5'i Ermeni milletine mensuptur. 22 suçlunun milliyetini ise tespit edebilmek mümkün değildir. Kadınların kalebent cezalarına dair herhangi bir veriye rastlanmamıştır. Gayrimüslimlere yönelik kalebent cezasina konu olan ceza mahalleri Amasya (1), Ankara (2), Antalya (3), Kala-i Sultaniye (1), Karahisar-1 Sahip (2), Kilidül-bahir (1), Dimetoka (31), İsakçı Kayseri (3), Kütahya (15), Niğde (1), Tokat (1), Sivas (1) olarak tespit edilmiştir. Toplamda 12 ayrı suç mahallinin varlığından bahsedildiği anlaşılmaktadır. Dimetoka ve Kütahya kaleleri ise tercih edilen kaleler arasında başı çekmiştir.

Cezalandırma işlemleri bireysel olarak yürütülmekle birlikte Kütahya’ya yapılan 12 kişilik toplu bir cezalandırılma uygulamasıyla da karşılaşılmıştır. 1824 yılında Der-saadet'te oluşturulan 12 kişilik çetenin Kefalonya, Zanta ve bazı adalar reayasından firıncı, bahçıvan, bakkal ve bazı başıboş Arnavut ve Rum milletinden reayayı 100-150 kuruş ücret almak karşılığında kaçırarak Hanya'ya götürülmelerine aracılık ettikleri tespit edilmiştir. Bunun üzerine Kefalonyalı Dürzi İspir, Haraco, İspir, Badet, Kimi kılaguzu Dimitri Katrinos, Zehariye Karlabonho, Kuyumcu Anderya Polos, Zantalı İspir, Kocaki, Kefalonyalı diğer İspir, Aldin, Şireli Boğci çırağ Çorci'nin Kütahya Kalesi'ne kalebent olarak (A.DVNS.KLB.d., 37, 104-5) gönderilmeleri kararlaştırılmıştır. Cezalandırma işlemlerinde suçluların gittikleri bölgede de bir araya gelerek yeniden suç faaliyetlerine yeltenmemeleri açısından farklı bölgelere gönderildiği bilinmekle birlikte burada bu hususa dikkat edilmediği anlaşılmaktadır.

\section{Manastırbent Cezaları}

1823-1826 yılları arasında tespit edilen araştırma sorularından dördüncüsü manastırbent cezalarını aydınlatmak olarak belirlenmiştir. Gayrimüslimler için dünyevi hayattan çekilip günahlardan arınmaya hizmet eden manastırlar, yerleşim merkezlerinden uzak yerlere kurulmuştur. Bu durum manastıra sürülmüş olan suçluların toplumdan soyutlanarak düşünmeye sevk edilmelerine olanak sağlamıştır (Tellan, 2019, s. 176). Manastırbentlik cezası kalebentlik cezasının gayrimüslimlere uygulanan hali olarak karşımıza çıkmıştır. Suçluların alıkonulması için hapishane binalarının bulunmayışı bu gibi cezaların tercih edilme nedenlerinden olmuştur.

Tablo 4

Manastırbent Cezalarının Uygulandığı Suç Çeşitleri, Hüküm Numaraları ve Mahkûm Sayıları

\begin{tabular}{llll}
\hline Sıra & \multicolumn{1}{c}{ Suç Çeşidi } & Hüküm Numarası & $\begin{array}{l}\text { Mahkûm } \\
\text { Sayısı }\end{array}$ \\
\hline 1 & $\begin{array}{l}\text { Ahalinin evine girip zarara } \\
\text { uğratmak }\end{array}$ & $121-1$. & 1 \\
& $\begin{array}{l}\text { Ahaliye tecrim / tekdir / taciz / } \\
\text { taaddi / zulüm etmek }\end{array}$ & $51-5$. & 1 \\
& Ayinlere mugayir hareket & $4-2,34-3,34-4,44-1,71-2,142-1,148-1,174-4$, & 14 \\
4 & Kendi halinde olmamak & $189-3,201-1,215-1,244-2,268-3,269-3$. & 1 \\
5 & Sebebi belli olmayan & $223-5$. & 1 \\
\hline
\end{tabular}

Dönemde manastırbent cezasına sebep olan 5 ayrı suç çeşidi ile karşılaşılmıştır. Bunlar ahalinin evine girip zarara uğratmak, ahaliye tecrim / tekdir / taciz / taaddi / zulüm etmek, ayinlere mugayir hareket, kendi halinde olmamak ve sebebi belli olmayan suçlar olarak tespit edilmiştir. Yine ayinlere mugayir hareket suç çeşidi nedeniyle manastırbentlik cezası alan gayrimüslim sayısının 
fazlalığı dikkat çekmektedir (Tablo 4). Bu ceza türü çoğunlukla gayrimüslim din adamlarına uygulanmıştır. 1823 yılında Rumeli taifesinden Gümülcine'de mütemekkin Kiryos adlı rahibin kendi halinde olmayarak ayinlerine mugayir hareket nedeniyle defaatle uyarılmış olsa da uslanmaması üzerine terbiyeye muhtaç olduğu için yasakçı marifetiyle Dubniçe kazasına bağlı Manastır'a gönderilmesi (A.DVNS.KLB.d., 37, 34-3) buna örnektir. Ceza süresinin 9 ay kadar sürdüğü (A.DVNS.KLB.d., 37, 34-4) anlaşılmaktadır. 1824 yılında ise eski Rum patriği Dimitos'un patrikliği döneminde sefil kimselere yüz vererek patrikhanenin nizamına aykırı hareket etmelerine göz yummak ve ayinlere mugayir hareketlere rıza göstermesi nedeniyle patriklikten azledilip Üsküdar civarında Kadı karyesine gönderilmiş ise de bu taraftan da azledilip Kayseri'ye bağlı Zincidere'deki Aya Prodromos Manastırı'na çavuş ve yasakçı mübaşiretiyle gönderilmesi (A.DVNS.KLB.d., 37, 142-1) bunun örneklerindendir. Devlet memurlarının cezalandırılma bölgesine gönderilmesi işini yalnız başına yasakçı üstlenmeyip çavuşların da onlara eşlik ettiğini söz konusu veriden yola çıkarak anlamak da mümkündür.

Kalebent cezasına konu olan kadın suçlu ile karşılaşılmamış olmakla birlikte manastırbent cezası verilen 3 kadın gayrimüslim suçlu ile karşılaşılmıştır. 1825 yılında Der-saadet’te Yeniköy mütemekkinlerinden Rum milletinden Kadinko kızı Haresto adlı zimminin defaatle uyarılmış olsa da bir müddetten kendi halinde olmayıp ayinlerine mugayir hareket nedeniyle Gemlik kazasındaki Odbiterya Kariler (Kızlar) Manastırı'na ıslah olması için yasakçı marifetiyle gönderilmesi (A.DVNS.KLB.d., 37, 269-3) buna örnektir.

Dönemde toplam 18 gayrimüslim suçlu ile karşılaşılmıştır. Bunların 12'si Rum, 5'i Ermeni ve 1'i de Dürzi'dir. 3 adet de kadın suçludan bahsedilmiştir. Manastırbentlik cezasına konu 14 ayrı ceza mahalli ile karşılaşılmıştır. Bunlar; Ayasora Manastırı / Kudüs (1), Aya yorgi Manastırı / Gemlik (1), Baçkova Manastırı / Filibe (1), Çanlı Manastırı / Muş (1), Çağrı Manastırı / Muş (1), Dubnice Manastırı / Kapudağı (2), Garipler Manastırı / Yozgat (1), Meryem Ana Manastırı / Gümüşhane (1), Meryem Ana Manastırı / Develi (1), Odbiterya Kızlar Manastırı / Gemlik (2), Sivas Manastırı (1), Vardam Manastırı / Tırhala (1), Yanartaş Manastırı /İncesu (1), Zincidere Aya Prodromos Manastırı / Kayseri (2) olarak tespit edilmiştir. Toplam 14 ayrı suç mahallinin varlığı anlaşılmaktadır. Manastırbent cezası alan suçlular hemen hemen her bir manastıra tek tek olmak üzere gönderilmiş̧ir.

\section{Palankabent Cezaları}

1823-1826 yılları arasında tespit edilen araştırma sorularından beşincisi palankabent cezalarını aydınlatmak olarak belirlenmiştir. Palanka Macarca'dan Osmanlıca'ya geçen ağaç ve toprakla yapılmış ve hendek çevrilmiş hisarcık anlamına gelen bir kelimedir (Sami, 2012, s. 346). Ağaç kütüklerinden koruyucu bir çitle çevrili basit bir kaleyi ifade etmektedir. Palankaları dağ başlarına inşa edilen muhkem yapılar olarak tanımlamak mümkündür. Askeri mimari çerçevesinde ufak bir garnizonu barındırmak amacıyla basit ve acele suretle inşa edilmişlerdir. Stratejik yerlere konumlandırılmasına önem verilmekte olup günlük ihtiyaçların karşılanabilmesi için arazinin doğal özellikleri de dikkate alınarak 1 ya da 2 kat olarak tasarlanmıştır (Eyice, 2020).

Tablo 5

Palankabent Cezalarının Uygulandı̆̆ Suç Çeşitleri, Hüküm Numaraları ve Mahkûm Sayıları

\begin{tabular}{llll}
\hline Sıra & Suç Çeşidi & Hüküm Numarası & Mahkûm Sayısı \\
\hline 1 & Ayinlere mugayir hareket & $89-3,244-3,253-3$. & 3 \\
\hline Toplam & & & 3 \\
\hline
\end{tabular}

Palankabentlik cezasının kalebentlik ya da manastırbentlik cezasına göre daha ağır bir ceza türü olduğu anlaşılmaktadır. Mahkûmlar oldukça dar yaşam alanlarında, zor şartlarda, kısıtlı imkânlarla yaşamını idame ettirmekle yükümlü tutulmuştur (Çeribaş, 2018, s. 76). Dönemde gayrimüslimlere yönelik verilen 3 palankabent cezası ile karşılaşılmıştır (Tablo 5). Bunların 2'si Rum olup diğerinin milliyeti belli değildir. Her üç suçlunun da Eğridere Palankası'na gönderildiği tespit edilmiştir. 1824 yılında Rum milletinden Manisa kazası Turgutlu kasabası mütemekkinlerinden 
Ekmekçi İsterati adlı zimminin defaatle uyarılmış olsa da kendi halinde olmayıp ayinlerine mugayir hareket nedeniyle Eğridere Palankası'na gönderilmesi (A.DVNS.KLB.d., 37, 89-3) buna örnektir. Ceza süresinin 5 ay kadar sürdüğü anlaşılmakta olup Tersane-i Amire'ye nezir ödemek şartıyla serbest bırakıldığ 1 (A.DVNS.KLB.d., 37, 134-3) verilerine ulaşılmıştır. Söz konusu veriden yola çıkarak mahkûmların serbest bırakılma şartı olarak nezir akçesi ödemek zorunda olduklarını ifade etmek mümkündür.

\section{Kürek Cezaları}

1823-1826 yılları arasında tespit edilen araştırma sorularından altıncı ve sonuncusu kürek cezalarını aydınlatmak olarak belirlenmiştir. Kürek cezaları hürriyet bağlayıcı niteliği bulunması bakımından diğer cezalardan ayrılmaktadır. Hapis cezalarından daha ağır bir nitelik taşımaktadır (Avc1, 2002, s. 138). Kürek cezası alan mahkûmlar ayaklarında demir olduğu halde meşakkatli işleri yapmakla yükümlü tutulmuştur (Poyraz, 2020, s. 510). Mahkûmlar devlet tarafından belirlenen iş alanlarında gücü nispetinde çalıştırılmıştır. Dönemde kürek cezasına nadiren başvurulduğu anlaşılmaktadır. Gayrimüslimlere yönelik uygulanan toplam 3 kürek cezası ile karşılaşılmıştır.

Tablo 6

Kürek Cezalarının Uygulandığı Suç Çeşitleri, Hüküm Numaraları ve Mahkûm Sayıları

\begin{tabular}{llll}
\hline \multirow{2}{*}{ Sıra } & Suç Çeşidi & $\begin{array}{l}\text { Hüküm } \\
\text { Numarası }\end{array}$ & $\begin{array}{l}\text { Mahkûm } \\
\text { Sayısı }\end{array}$ \\
\hline 1 & Ayinlere mugayir hareket \\
2 & $\begin{array}{l}\text { Kendi halinde olmamak / Ruhaniyete aykırı hareket } \\
\text { etmek }\end{array}$ & $134-1$. & 1 \\
\hline Toplam & & $269-1,280-1$. & 2 \\
\hline
\end{tabular}

Dönemde kürek cezasına sebep olan suç çeşitleri ayinlere mugayir hareket ve kendi halinde olmamak (ruhaniyete aykırı hareket etmek) olarak tespit edilmiştir (Tablo 6). Kürek cezası alan gayrimüslim unsurların 1'i Rum, 1'i Ermeni olup diğerinin milliyetini ise tahmin etmek mümkün değildir. Kürek cezası alan gayrimüslim kadın suçluya rastlanmamıştır. Kürek cezası alan suçluların hepsinin de Tersane-i Amire'ye gönderildiği anlaşılmaktadır. 1824 yılında Ermeni milletinden Sapanca kazası mütemekkinlerinden Magdis Bedros adlı zimminin kendi halinde olmayıp ayinlerine mugayir hareket nedeniyle terbiyesi lazım geldiği düşünülerek küreğe konulması (A.DVNS.KLB.d., 37, 134-1) ve 1826 yılında Cisr-i Ergene kazasına tabi Beğendik karyesi mütemekkinlerinden Rum taifesinden Küçük Papa Yorgi adlı rahibin kendi namusuna sahip olmayıp ayin ve ruhaniyete aykırı hareket etmesi nedeniyle defaatle uyarılmış olsa da slah olmadığ gerekçesi ile küreğe konulması (A.DVNS.KLB.d., 37, 280-1) bunun örneklerindendir. Mahkûmlara çalıştıkları bu ağır bedeni işler karşılığında belli bir ücret ödenmesi karara bağlanmış olup, firarlarını engelleyebilmek amacıyla ödemelerin ancak tahliye durumlarında gerçekleştirildiğini (Poyraz, 2020, s. 510) ifade etmek mümkündür.

\section{Sonuc}

Osmanlı Devleti'nin yaklaşık 150 yıllık ağır ceza tarihine 1şık tutan kalebent defterleri oldukça önemli veriler içermesi bakımından dikkate değerdir. II. Mahmut döneminin bir kesiti olarak 18231826 y1lları arasındaki döneme dair verileri içeren 37 numaralı Kalebent Defteri'nin gayrimüslimlere yönelik hükümlerinden yola çıkarak ağır cezalara konu olan ceza türleri irdelenmiştir. Ceza türlerine sebep olan suç çeşitleri ise tablolarda sunulmuştur. Deftere konu olan ceza türleri sürgün, ikamet, kalebent, manastırbent, palankabent ve kürek olarak belirlenmiştir. Sürgün cezasına sebep olan 23, kalebent cezasına 9, manastırbent cezasına 5, palankabent cezasına 1, kürek cezasına 2 suç çeşidinin varlığı tespit edilmiştir.

Defterde cezalandırılma bölgelerinin farklılı̆g 1 dikkat çekmektedir. Bu neden oldukça çok cezalandırılma bölgesinin varlığı ile karşılaşılmıştır. Sürgünde 49 , kalebentte 12 , manastırbentte 14 , palankabentte 1 bölge ismine yer verilmiştir. Kürek cezası için ise Tersane-i Amire seçilmiştir. 
Dönemde toplu af uygulamasına rastlanmamıştır. Suçluların salıverilmesi için belgelerde 1slah-1 nefs ibaresine yer verilmiştir. Islah-1 nefs eden suçluların salıverilmesine yönelik hükümlerin üzerine şerhler düşülmüş̧ür. Bu şerhlerden yola çıkarak cezalandırılma ve salıverilme tarihleri arasındaki farkları belirleyerek ortalama ceza süresini tahmin edebilmek mümkün olmuştur. Itlak hükümlerinin yer aldığı şerhlerden yola çıkarak sürgün cezalarının 3 ay ile 56 ay arasında, kalebent cezalarının 3 ay ile 19 ay arasında, manastırbent cezalarının 3 ay ile 20 ay arasında değiştiği ve palankabent cezasının ise 5 ay kadar sürdüğü verilerine ulaşılmıştır.

Cezalar tatbik edilmeden önce suçluların huzur bozucu davranışlardan uzaklaşmaları için defaatle uyarıldığı, kötü davranışlara devam edildiği sürece cezalandırıldığı anlaşılmıştır. Suça konu olan eylemlerin toplumsal etkisinin büyüklügü ceza türünün belirlenmesindeki temel etken olmuştur. Tespit edilen ceza türleri aktarılırken en hafiften en ağıra doğru kademelendirilmiş̧tir. Müslümanlar ile kıyaslandığında gayrimüslimlerin çok daha az suç eylemine karıştığı tespit edilmiştir. Ağır cezalar içerisinde sürgün cezaları başı çekmiştir. Sürgün cezalarını ise kalebentlik cezaları takip etmiştir.

Ceza türlerine sebep olan suç çeşitlerinin hemen hemen bütün cezalar için aynı olduğu görülmüştür. Ayinlere mugayir hareket suç çeşidi hemen hemen bütün ceza türlerinde baş1 çekmiştir. Onu kendi halinde olmamak ve hilaf-1 rıza hareket suç çeşitleri takip etmiştir. Cezalandırma hareketliliğinin çoğunlukla Anadolu coğrafyasında yaşandığı anlaşılmaktadır. Sürgün cezası alan suçlular için çoğunlukla Tokat ve Dimetoka, kalebent cezası alan suçlular için Dimetoka ve Kütahya, manastırbent cezası için Gemlik başı çeken bölgeler olmuştur. İkamet cezası alan suçlular için İznikmid ve Hüdavendigar, palankabent cezası için Eğridere Kalesi, kürek cezası için ise Tersane-i Amire tercih edildiği verilerine ulaşılmıştır.

Gayrimüslimlerin milli kimliklerine göre suç dağılımını da tespit etmek mümkündür. Buna göre sürgün cezası alan 40 Ermeni, 19 Rum; kalebent cezası alan 30 Rum, 5 Ermeni; manastırbent cezası alan 12 Rum, 5 Ermeni; palankabent cezası alan 3 Rum; kürek cezası alan 2 Rum, 1 Ermeni ve ikamet cezası alan 1 Bulgar tespit edilmiştir. Diğerlerinin ise milliyet kimliklerine dair verilere yer verilmemiştir. Deftere konu olan az sayıda da olsa gayrimüslim kadın suçlu ile karşılaşılmıştır. Karşılaşılan 11 kadın suçludan 8'ine sürgün, 3'üne manastırbentlik cezası verilmiş̧ir. Söz konusu ceza türlerine sebep olan suç çeşitleri ise ayinlerine mugayir hareket, ahalinin evine girip zarara uğratmak, ahalinin huzurunu bozmak ve Ermeni reaya kızlarını Avrupalılarla evlendirmek olarak belirlenmiştir.

Gayrimüslim din adamlarının cemaati tarafindan işlenen suçları arzuhallerle merkeze bildirmekle mükellef olduğu verilerine ulaşılmıştır. Onların dilekçeleri doğrultusunda hükümlerin karara bağlandığı anlaşılmaktadır. Af talepleri konusunda da yine aynı yöntemin izlendiğini ifade etmek mümkündür. Gayrimüslim suçluların Müslümanlardan farklı olarak ceza bölgelerine yasakçı vasıtasıyla gönderildiği verilerine ulaşılmıştır. Suçluları ceza mahallerinde harbeciler teslim almış, ceza takip işlemlerini ise yerel yetkililer olan kadılar takip etmiştir. Deftere konu olan dönemin Yeniçeri Ocağı'nın kaldırılmasından hemen önceki sürece denk gelmesi nedeniyle askerlikle ilgili cezalandırılma hükümlerinin ayrıca incelemeye tabi tutulması gereken bir sonuç olarak karşımıza çıkmıştır.

\section{Yazarların Katkı Oranı} vardir.

Bu çalışmaya birinci yazarın \%40, ikinci yazarın \%30, üçüncü yazarın $\% 30$ oranında katkısı

\section{Çıkar Çatışması}

$\mathrm{Bu}$ çalışmada çıkar çatışması oluşturacak herhangi bir husus yoktur. 


\section{Kaynaklar}

Acehan, A. (2008). Osmanlı Devleti’nin sürgün politikası ve sürgün yerleri. Uluslararası Sosyal Arastırmalar Dergisi, 1(5), 12-29.

Akgündüz, A. (2006). Osmanlı kanunnameleri ve hukukî tahlilleri / Osmanlı hukukuna girişs ve fatih devri kanunnameleri (Cilt 1). İstanbul: OSAV.

Akgündüz, A. (1991). Osmanl kanunnameleri ve hukuki tahlilleri / Yavuz Sultan Selim devri kanunnameleri (Cilt III). İstanbul: OSAV.

Avcı, M. (2002). Osmanlı uygulamasında infazı özellik gösteren hapis türleri: kalebentlik, kürek ve prangabentlik. Yeni Türkiye Dergisi Türkoloji ve Türk Tarihi Araştırmaları Özel Sayısl, III(45), 128-148.

Baytimur, S. O. (2011). Osmanlı Devleti'nde hapis ve sürgün cezalarl (1791-1808). Doktora Tezi. F1rat Üniversitesi, Sosyal Bilimler Enstitüsü, Elazı̆̆.

BOA (T.C. Cumhurbaşkanlığı Devlet Arşivleri Başkanlığı Osmanlı Arşivi), A.DVNS.KLB.D., nr. 37 (Divan-1 Hümayun Defterleri Kataloğu, Kalebend Defterleri)

Çeribaş, V. (2018). 33 numaralı kalebend defteri (s.1-133/H-1227-1229/M-1812-1814). Yüksek Lisans Tezi.Mimar Sinan Güzel Sanatlar Üniversitesi, İstanbul.

Ergin, K. (2016). Osmanlı Devleti'nde kanunnamelerden nizamnamelere geçiş. Süleyman Demirel Üniversitesi Fen-Edebiyat Fakültesi Sosyal Bilimler Dergisi, (39), 1-26.

Erim, N. (1984). Osmanlı İmparatorluğunda kalebentlik cezası ve suçların sınıflandırılması üzerine bir deneme. Osmanlı Araştırmaları, 4, 79-88.

Gökçen, A. (1987). Tanzimat dönemi Osmanlı ceza kanunları ve bu kanunlardaki ceza müeyyideleri. Yüksek Lisans Tezi. İstanbul Üniversitesi Sosyal Bilimler Enstitüsü, İstanbul.

Güneş, G. A. (2015). Osmanlı Devleti'nin gayrimüslimlere bakışı ve klasik dönem millet sistemi. Sosyal ve Kültürel Araştırmalar Dergisi, 1(2), 1-30.

Halaçoğlu, Y. (2014). XVIII. yüzyılda Osmanl Imparatorluğunda iskan siyaseti ve aşiretlerin yerleştirilmesi. Ankara: TTK Yayınları.

Heyd, U. (1984). Osmanlı ceza hukukunda kanun ve şeriat. Ankara Üniversitesi Illahiyat Fakültesi Dergisi, (26), 633-652.

Koç, Y., ve Tuğluca, M. (2006). Klasik dönem Osmanlı ceza hukukunda yargılama ve toplumsal yapı. Türk Hukuk Tarihi Araştırmaları, (2), 7-24.

Köksal, O. (2006). Osmanlı hukukunda bir ceza olarak sürgün ve iki Osmanlı sultanının sürgünle ilgili Hatt-1 Hümayunları. Ankara Üniversitesi Osmanlı Tarihi Araştırma ve Uygulama Merkezi Dergisi, (19).

Poyraz, Ö. (2017). Abdülmecid döneminde gayrimüslimlere verilen bireysel nefy (sürgün) cezaları. O. Köse (Ed.) İçinde Geçmişten Günümüze Göç (Cilt 1) (ss. 265-284) Samsun: Canik Belediyesi Kültür Yayınları.

Poyraz, Ö. (2020). Abdülmecid dönemi hürriyet bağlayıcı ve kısıtlayıcı ceza uygulamalarına dair bir inceleme. Selçuk Üniversitesi Edebiyat Fakültesi Dergisi, (43), 497-518. 
Sami, Ş. (2012). Kamus-i Türki. Balıkesir: Altınpost Yayınevi.

Saydam, A. (1999). Osmanlı medeniyeti tarihi. Tabzon: Derya Kitabevi.

Taner, T. (1940). Tanzimat devrinde ceza hukuku. İçinde Tanzimat 1 (ss. 221-232). İstanbul: Maarif Matbaasi.

Tellan, E. B. (2019). Osmanlı araştırmalarında yeni kaynakların tarih yazımına katkıları: Manastırbend örneği. Tarih Yayımı Dergisi, 1(2), 171-190.

Uz, R. (2018). Osmanlı tarih çalışmalarında kalebent defterlerinin rolü. İçinde Tarihin Peşinde Bir Ömür (Abdülkadir Özcan'a armăgan), (ss. 447-464). İstanbul: Kronik Kitap

Ünal, M. A. (2011). Osmanlı tarihi sözlüğ̈̈̈. İstanbul: Paradigma Yayınları.

Yakut, E. (2006). Tanzimat dönemine kadar osmanlı hukukunda ta'ziri gerektiren suçlar ve cezaları. Türk Hukuk Tarihi Araştırmaları, (2), 25-40.

Yurtseven, Y. (2001). Klasik dönem Osmanlı ceza hukukunda ta'zir suç ve cezaları. Selçuk Üniversitesi Hukuk Fakültesi Dergisi, 4(3-4), 265-292. 


\section{Extented Abstract}

This study deals with the $2^{\text {nd }}$ Mahmut period. It has been prepared on the axis of 37 Numbered Fortress Book. The book which written with divani calligraphy covers the heavy penalties of the period between 1823-1826. This study was initiated by presenting the characteristics of 37 Numbered Fortress Book and it was continued with the presentation of severe punishment types. The severe punishment types are examined under 6 different headings. These are exile, fortress, monastic punishment, military castle penalty, servitudes and shackles. Among these provisions, those for nonMuslims have been classified. Non-Muslims' crime and criminal profiles has been revealed. It has been found that 42 different types of crime causing all punishments were applied to 175 separate prisoners.

The heavy penalties covered in the book have similar and different characteristics. Exile criminals were sent from one region to another and expected to live in there for a certain period of time. Residence criminals were expected to reside in a region by force. Fortress criminals were expected to live for a certain period of time by not leaving the desingned castle boundaries. Monastic criminals were expected to reside in the monasteries far from worldly life within the specified. Military castle criminals were expected to serve their sentences in the military barracks built on the mountain tops. Therefore, it is possible to state that there is an exile in all these punishments. Criminals of servitude and shackles are also relatively different from other punishment in that they have to work for a certain period of time in jobs determined by the state with shackles on their feet.

The Ottoman State applied the same types of punishment to all criminals, regardless of whether they are Muslim or non-Muslim. It has been understood that in all severe punishments, the aputhority of approval and amnesty belongs only to the Sultan. The absence of existing prison building has led to such severe penalties. In the provisions in the book, first of all, information about the place of the incident and the place where the penalty will be taken is provided. While writing the sentences, information about the crime scene, name, title, religious affiliation, nationality, cause of crime, the method of punishment to be applied and the place of punishment are included.

It has been found that non-Muslims are less involved in criminal acts than Muslims. 151 nonMuslim criminals were encountered. It was determined that if the criminals were involved in a second criminal act, they received a new heavy sentence. The second penalties were heavier than the first. The distribution of punishment types has been determined as follows: 92 exile criminals, 57 fortress criminals, 18 monastic criminals, 3 military castle criminals, 3 servitudes and shackles criminals and 2 residence criminals. Among the heavy penalties in question, it is possible to define the exile and residence penalties as lighter penalties. Servitudes and shackles has been the heaviest punishment. It was determined that there were 23 types of crimes that caused exile, 9 that caused fortress penalty, 5 that caused a monastic punishment, 1 that caused military castle penalty and 2 that caused servitudes and shackles. Different regions have been chosen as penalty areas. 49 in exile, 12 in fortress, 14 in monastery punishment, 1 in military castle penalty were preferred. Tersane-i Amire was preferred for the punishment of slavery and shackles.

During the period, no data was encontered showing that heavy penalties were collectively forgiveness. In some special cases, individual amnesties have been encountered. Criminals were expected to be free of bad behavior in order to be released. Annotations have been written on the provision regarding the release of criminals who are corrected. Based on these annotations, it is possible to determine the differences between the dates of punishment and release and to estimate the average penalty period. The punishments for exile ranged from 3 months to 56 months, fortress sentences from 3 months to 19 months, monastic punishments from 3 months to 20 months and military castle penalty punishments lasted to 5 monhts.

The types of crimes in the book have been determined as disturb the peace of the people / persecution of the people, movement against rituals, unscrupulous act, betrayal to the mint, marrying Armenian reaya girls to Europeans, supporting the former Greek patriarch, sedition anf mischief, 
disrupting the price order, act against consent, improper tax collection, infringement, cruelty to the people, not being busy with his own business, disturbing the mines, disturb the order, breaking the mukataa order, breaking into and harming the people's house, revolution and bankruptcy to the contry, intervention in patriarchate affairs, forged documents, non-sharia and immoral behavior, rape / prostitution, requiring improvement acts, improper movement in the shipyard cellar, misconduct / misbehavior, not to examine ammunition delivered, preparing forged documents, intervene in nonduties jobs, failure to fulfill his duty and uncertain reason.

Before the punishments were applied, it was understood that the criminals were warned several times to avoid disturbing behaviors and punished as long as they continued bad behavior. The extent of the social impact of criminal acts has been the main factor in determining the type of punishment. The types of crime that caused the punishment types were almost the same for all punishments. The type of act crime, which is contrary to rituals, took the lead in all types of punishment. Punishment mobility was mostly experienced in the Anatolian geography. Mostly Tokat and Dimetoka were preferred for exile punishment, Dimetoka and Kütahya for fortress punishment and Gemlik for monastic punishment. İznikmid and Hüdavendigar were chosen fort he residence penalty, Eğridere castle for military castle penalty and Tersane-i Amire for the penalty of servitudes and shackles. It has also been possible to reach the nationalities of the criminals. While 40 Armenians and 19 Greeks had been sentenced to exile, 30 Greeks and 5 Armenians had been sentenced to fortress. While 12 Greeks and 5 Armenians had been sentenced to monastic penalty, 3 Greeks had been castle penalty and 2 Greeks, 1 Armenian and 1 Bulgarian had been sentenced the hard penalty, too. The nationalities of the others could not be determined. A small number of non-Muslim female criminals were also encountered. While 8 women were sent into exile, 3 womens were sentenced to the monastery. It was determined that non-Muslim clergymen took an active role in the penalty process. 